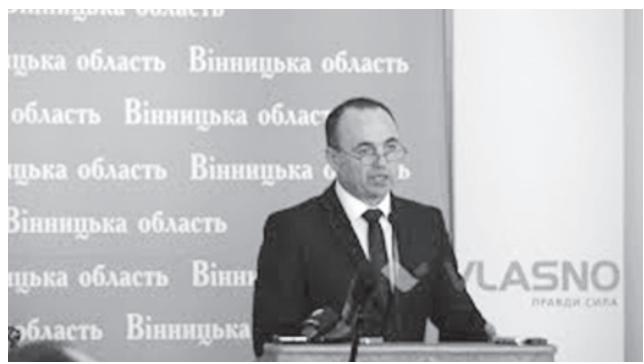

УДК 342.571:351.9]:352

https://doi.org/10.32689/2617-2224-

2020-5(25)-120-134

Кулешов Володимир Володимирович, аспірант кафедри регіональної політики та публічного адміністрування, Одеський регіональний інститут державного управління Національної академії державного управління при Президентові Украӥни, 65062, м. Одеса, вул. Генуезька, 22, тел.: (096) 223-77-07, е-таіl: volodkulesh2020@gmail.com, https://orcid.org/0000-0003-2270-2823

Кулешов Владимир Владимирович,

аспирант кафедры региональной политики и публичного администрирования, Одесский региональный институт государственного управления Наииональной академии государственного управления при Президенте Украины, 65062, г. Одесса, ул. Генуэзская, 22, тел.: (096) 223-77-07, e-mail: volodkulesh2020@gmail.com, https://orcid. org/0000-0003-2270-2823

Kuleshov Volodymyr Volodymyrovych, postgraduate student of the Department of Regional Policy and Public Administration, Odessa Regional Institute of State Administration of the National Academy of State Administration under the President of Ukraine, 65062, Str. Genuezka, 22, tel.: (096) 223-77-07, e-mail: volodkulesh2020@gmail.com, https://orcid.org/0000-0003-2270-28233

\title{
ТЕОРЕТИКО-МЕТОДОЛОГІЧНІ ЗАСАДИ ГРОМАДСЬКОГО КОНТРОЛЮ ПРЕДСТАВНИЦЬКИХ ОРГАНІВ ВЛАДИ В УМОВАХ ДЕЦЕНТРАЛІЗАЦІї
}

Анотація. Розглянуто теоретико-методологічні засади громадського контролю представницьких органів влади в умовах децентралізації. Проведено аналіз зарубіжних наукових джерел, що дозволило виокремити широкий спектр досліджень громадського контролю представницьких органів влади та надало можливість систематизувати теоретико-методологічні засади формування та розвитку такого контролю за напрямами досліджень. Узагальнення сутності теорій, концепцій, підходів, шкіл зарубіжної науки продемонструвало широкий діапазон їх практичного застосування для діяльності публічних адміністрацій у побудові взаємовідносин з громадою в аспектах: самостійного прийняття рішень у сфері політики та розподілення ресурсів; формування сильних громад, які контролюють і координують дії по відношенню до держави; виборчого процесу та розподілення відповідальності; взаємодії з обраними в представницькі органи влади; здійснення влади; впливу об'єднань 
громадян на застосування законів і політики (публічної політики) на сфери життєдіяльності населення; участі громадськості та державних управлінців в плануванні та реалізації розвитку громади; впливу громадськості на кризи на місцевому рівні; соціальної роботи; процесу залучення громадян до процедури контролю тощо.

Проведений аналіз наукових джерел продемонстрував відсутність у вітчизняній науковій думці теоретико-методологічних засад і теорій громадського контролю як явища і як процесу, зокрема за представницькими органами влади в умовах децентралізації. Здебільшого йдеться про форми, методи, технології, інструменти та процедури громадського контролю, які часто дорівнюються до методів залучення громадян у процес прийняття рішень на різних рівнях управління.

Аналіз наукових поглядів на формування та розвиток контролю дав змогу узагальнити сфери громадського контролю представницьких органів влади, класифікувати їх за сферами публічного управління, а відповідно до змісту, сенсу та характеристик теорій, за сферами впливу на життєдіяльність населення. Продемонстровано, що громадський контроль представницьких органів влади - це одна з форм взаємовідносин публічної адміністрації 3 громадою.

Ключові слова: громадський контроль, теорії громадського контролю; сфера громадського контролю; представницькі органи влади; децентралізація.

\section{ТЕОРЕТИКО-МЕТОДОЛОГИЧЕСКИЕ ОСНОВЫ ГРАЖДАНСКОГО КОНТРОЛЯ ПРЕДСТАВИТЕЛЬНЫХ ОРГАНОВ ВЛАСТИ В УСЛОВИЯХ ДЕЦЕНТРАЛИЗАЦИИ}

Аннотация. Рассмотрено теоретико-методологические основы общественного контроля представительных органов власти в условиях децентрализации. Проведен анализ зарубежных научных источников, что позволило выделить широкий спектр исследований общественного контроля представительных органов власти, а также систематизировать теоретико-методологические основы формирования и развития такого контроля по определенным направлениям исследований. Обобщение сущности теорий, концепций, подходов, школ зарубежной науки показало широкий диапазон практического применения в процессе деятельности публичных администраций в построении взаимоотношений с обществом в аспектах: самостоятельного принятия решений в сфере политики и распределения ресурсов; формирования сильных сторон общин, которые контролируют и координируют действия по отношению к государству; избирательного процесса и распределения ответственности; взаимодействия с избранными в представительские органы власти; влияния объединений граждан на действие законов и политики (публичной политики) на сферы жизнедеятельности населения; участия общественности и публичных служащих в планировании и реализации развития общин; влияния общественности на кризисную ситуацию на мест- 
ном уровне; социальной работы; процесса вовлечения граждан в процедуру контроля и т. д.

Анализ научных источников показал отсутствие в отечественной научной мысли теоретико-методологических основ теорий общественного контроля как явления, так и процесса, в частности представительными органами власти в условиях децентрализации. В основном речь идет о формах, методах, технологиях, инструментах и процедурах общественного контроля, что часто приравниваются к методам привлечения граждан в процесс принятия решений на разных уровнях управления.

Представленные в статье результаты проведенного исследования позволяют обобщить сферы гражданского контроля представительных органов власти, классифицировать их по сферам публичного управления, в соответствии с содержанием, смыслом и характеристиками теорий, по сферам влияний. Продемонстрировано, что общественный контроль - это одна из форм взаимоотношений публичной администрации с обществом.

Ключевые слова: гражданский контроль, теории гражданского контроля; сфера гражданского контроля; представительные органы власти; децентрализация.

\section{THEORETICAL AND METHODOLOGICAL FUNDAMENTALS OF PUBLIC CONTROL OF THE REPRESENTATIVE BODIES OF AUTHORITY IN THE CONDITIONS OF DECENTRALIZATION}

Abstract. The article considers the theoretical and methodological principles of public control of the representative bodies of authority in the context of decentralization. The analysis of foreign scientific sources is carried out, which allowed to single out a wide range of researches of public control of the representative bodies of authority and gave the chance to systematize the theoretical and methodological bases of formation and development of such control on directions of researches. The generalization of the essence of theories, concepts, approaches, schools of foreign science has demonstrated a wide range of their practical application for the activities of public administrations in building relationships with the community in the following aspects: independent decision-making in the field of policy and resource allocation; formation of strong communities that control and coordinate actions in relation to the state; election process and distribution of responsibilities; interaction with those elected to the representative bodies of authority; exercise of power; the influence of citizens' associations on the application of laws and policies (public policy) on the spheres of life of the population; participation of the public and public officials in planning and implementing the community development; public influence on crises at the local level; social work; the process of involving the citizens in the control procedure, etc.

The analysis of scientific sources showed the absence in the domestic scientific opinion of theoretical and methodological principles and theories of public control as a phenomenon and as a process, in particular for the representative bodies of authority in the context of decentralization. These are mostly forms, methods, 
technologies, tools and procedures of public control, which are often equal to the methods of involving the citizens in the decision-making process at different levels of government.

The analysis of scientific views on the formation and development of control allowed to generalize the areas of public control of the representative bodies of authority, to classify them by areas of public administration, and in accordance with the content, meaning and characteristics of theories, by areas of impact on the vital activity of the population. It has been demonstrated that public control of the representative bodies of authority is one of the forms of public administration's relationship with the community.

Keywords: public control, theories of public control; sphere of public control; representative bodies of authority; decentralization.

Постановка проблеми. У сучасних демократичних країнах інститут громадянського контролю характеризується як невід'ємна частина здійснення управлінської діяльності та виступає дієвим інструментом впливу на публічну політику з боку громадськості. Підвищення ефективності сфери публічного управління та адміністрування має відбуватися за умов запровадження принципів прозорості та відкритості в діяльність усіх секторів суспільного життя, зокрема в діяльність органів публічного управління та адміністрування. У вітчизняних наукових джерелах існує велика кількість робіт, присвячених механізмам, формам, методам та процедурам здійснення громадського контролю. Втім, зарубіжні теоретико-методологічних засад щодо формування та розвитку громадського контролю представницьких органів влади, у тому числі в умовах децентралізації продемонстрував, що дослідження стосуються кількох напрямів, зокрема: розподілення влади між політиками та урядами; економічних теорій, яких дотримується уряд на формування підтримки у населення; соціологічних теорій, які стосуються соціального контролю в різних ситуаціях; теорії нового публічного управління, що змінює розуміння процесів публічного управління та адміністрування і виводить роботу уряду на новий результативний рівень; теорій політичного контролю, сутність яких розширилась і стала застосовною у вимірі взаємодії кількох секторів; теорій та концепцій, в основу яких покладено участь громадян та їх вплив на процеси демократичного прийняття рішення в публічному управлінні та адмініструванні.

У вітчизняній науковій думці відсутнє єдине розуміння категорій “громадський контроль” та “громадський контроль представницьких органів влади". Останній досліджується за окремими сферами суспільного життя або публічного управління та адміністрування, що призводить до вироблення окремих методологічних підходів щодо організації даного контролю відповідно до наукових галузей, в яких проводяться дослі- 
дження (політологія, економіка, соціологія, кібернетика). Відповідно і методологічні засади практичної реалізації такого виду контролю різняться залежно від застосовної у відповідній галузі науки методології.

Наукові дослідження стосуються здебільшого адміністративної сфери, де громадськості відводяться дорадчі функції, такі як: вплив на суспільні рішення; право прямого голосу в громадських рішеннях та право голосу при прийнятті рішень у сфері публічної політики; участь населення в плануванні певних дій або зусиль щодо розвитку громади; залучення до державного планування і розробки політики; приватність життя; впливи (психологічні, цілеспрямовані тощо). Основний акцент робиться на дослідженнях в адміністративній та публічній сферах у різних галузях наук. 3 такої позиції саме зарубіжні наукові погляди виступають основою для формування громадського контролю представницьких органів влади.

Аналіз останніх досліджень і публікацій. У вітчизняних та зарубіжних наробках існує значна кількість робіт, присвячених громадському контролю, методам, формам та процедурам його здійснення. Аналіз вітчизняних наукових досліджень продемонстрував відсутність єдиного сталого погляду на громадський контроль як явище і як процес в державному управлінні та в діяльності органів місцевого самоврядування. Практично відсутні наукові дослідження щодо особливостей громадського контролю в умовах децентралізації та методології цієї роботи на різних рівнях місцевого самовряду- вання. Здебільшого акцент робиться на організаційно-управлінських характеристиках організації громадського контролю та відповідальності за його результати. У результаті аналізу визначено існування широкого спектру тлумачень громадського контролю в контексті суб'єктоб'єктних відносин органів державної влади і місцевого самоврядування, зокрема: форм; механізмів; впливів; діяльності; взаємодії; взаємовідносин; зворотного зв'язку; активності громадян; систем контролю; функцій; способів; методів; інструментів; права; процесів; механізмів.

Аналіз зарубіжної наукової літератури дав змогу виокремити низку теоретичних підходів щодо підгрунтя формування громадського контролю органів представницької влади. Це погляди дослідників Dr. Almon Leroy Way, Jeanet Bentzen, Jacob Gerner Hariri, James A. Robinson, William A. Galston щодо розподілення влади між політиками та урядами. Наступна група науковців Randall G., Mark C. Schug, Jennifer Fontanini виокремлює вплив економічних теорій, яких дотримуються представницькі органи влади з метою формування підтримки у населення. Також акцентується увага на соціологічних теоріях, які стосуються соціального контролю в різних ситуаціях, зокрема схильності при налагоджені взаємодії органів влади з громадськістю. У наукових дослідженнях Ashraf Alam, Kabir M., Nazmul Ahsan Kalimullah наголос зроблено на теорії нового публічного управління, яка змінюе розуміння процесів публічного управління та адміністрування і виводить 
управлінську діяльність на новий результативний рівень. Серед багатоманітності наукових поглядів слід виокремити теорію політичного контролю, представником якої є дослідник Т. М. Мое, сутність яких розширилась і стала застосовною у вимірі взаємодії кількох секторів (політичного, управлінського та громадського). У наступну групу теорій та концепцій, розробниками яких є Ashley E. Nickels, Jason D., Joan Higgins, покладено участь громадян та їх вплив на процеси демократичного прийняття рішення в публічному управлінні та адмініструванні. Існують наукові погляди на сутність і процеси політичної децентралізації, яка передбачає розвиток громадського контролю представницьких органів влади. Даний підхід відображено в наукових працях N. Van Long. Водночас, ці теорії знаходяться в певній залежності, але не об'єднані у систему. У багатьох дослідженнях йдеться про те, що кожна з теорій стала підгрунтям формування методів та інструментів громадського контролю у такій сфері, як фінансова, соціальна, інформаційна, адміністративна тощо. Втім, відсутні комплексні дослідження щодо систематизації наукових поглядів на формування та розвиток громадського контролю представницьких органів влади та відсутні наукові дослідження за сферами впливу на життєдіяльність населення.

Мета статті - проаналізувати та систематизувати наукові погляди на формування та розвиток громадського контролю, узагальнити сфери громадського контролю представницьких органів влади, класифікувати їх за сферами публічного управління, а у відповідності зі змістом, сенсом та характеристиками теорій, концепцій, шкіл тощо за сферами впливу на життєдіяльність населення.

\section{Виклад основного матеріалу.} Аналіз зарубіжної наукової літератури дав змогу виокремити низку теоретичних підходів щодо підгрунтя формування громадського контролю органів представницької влади. Зокрема, це погляди щодо розподілення влади між політиками та урядами [1], яке розглядається 3 кількох позицій.

3 позииї розподілення влади. Політика відноситься до проблем розподілення i використання влади в суспільстві, а уряд відносять до політичного інституту, за допомогою якого ця влада розподіляється і здійснюється. У цьому контексті державу розглядають як політичну одиницю, в якій знаходиться влада. Уряд визначається як група осіб, які керують політичними справами держави, але також може означати тип правління, яким керує ціла держава. Тип уряду, фундаментальні основи розуміння свободи, заможність i piвень життя населення залежить від політичної системи, яка існує в державі [1].

Система представницької демократії заснована на принципі політичного представництва - здійсненням законодавчої влади представниками, вибраними населенням. Репрезентативна демократія характеризується наявністю і функціонуванням представницьких інститутів прийняття політичних рішень, які складаються з державних посадових осіб, які обираються населенням [2]. 
В основі цих підходів лежить політична теорія. Втім, представники цієї теорії піддають критиці демократію, яку вважають не демократичною, оскільки одна людина не може представляти інтереси іншого.

Виокремлюється теорія модернізації, сутність якої в погляді на причина демократії та ролі уряду, участь якого розглядається як опосередкований продукт економічного розвитку. Вважається, що ці теорії не діють у сучасному світі, особливо там, де $є$ корінні народи та існують такі демократичні практики, як правонаступництво лідерів шляхом виборів або громадського консенсусу. Це демонструє сучасну представницьку демократію на національному рівні. Політично більш сильні суб'єкти змогли сформувати національні інститут, більш слабкі - не змогли [3].

Виокремлено роль впливу економічних теорій, в рамках яких робиться наголос на ролі уряду та формування підтримки з боку громадськості. Так, ще у 1997 р. йшлося про ті проблеми, з якими і зараз стикаються уряди багатьох держав. Randall G. (1997 р.) аналізує низку теорій, які призвели до формування позитивної моделі управління як противаги низці теорій, які можуть викликати бунти і революції серед населення при неможливості сформувати ефективний контроль. Розглядається негативний вплив теорії суспільних благ, яка пояснює розвиток і використання суспільних благ і яка виправдовує державне свавілля. Все розглядається крізь призму раціональної користі, коли уряд знижує витрати на уряд задля залучення уваги громадян до подальшої підтримки уряду. Акцент робиться на державній освіті, яка надає уряду більше контролю через систему освіти, а оскільки освітяни у зарубіжних державах - це державні службовці, то вони також зацікавлені в діяльності уряду. Також вплив через освіту відбувається на студентів, щоб зробити їх “кращими громадянами”, які визначають уряд як інститут, який відображає суспільний інтерес [4].

3 позииій прийняття рішень. Вважається, що у будь-якому суспільстві мають прийматись рішення відносно розподілення ресурсів та інших питань. Тільки у дуже простих суспільствах, конкретні люди і конкретні організації приймають рішення. Залежно від суспільства, рішення приймаються, іноді, виключно задля користі певних груп, у інших випадках - для того, щоб принести користь суспільству [1].

3 позиіі теорій, які лежать в основі політичного устрою та рівня розвитку представнищької вла$\partial u$. Теорія плюралізму передбачає, що асоціації, громадські організації, профспілки, захисники оточуючого середовища, борці за громадянські права, формальні і неформальні коаліції однодумців впливають на застосування законів і політики. Оскільки учасники цього процесу складають лише крихітну частину населення, громадськість виступає, здебільшого, як сторонні спостерігачі. Теорія функціоналізму приймає форму теорії плюралізму, яка констатує, що політична влада в демократіях поділена між кількома "групами вето".

William A. Galston (2017) [5] стверджує, що демократія на базовому рівні вимагає як рівності всіх гро- 
мадян, так і широкого громадянства. Враховується, що публічні рішення приймаються більшістю громадян, чиї голоси мають однакове значення, а прийняття демократичних рішень розповсюджуються на максимально широке коло суспільних питань. Наголошується, що мажоритарність обмежується тільки імперативом збереження свобод і повноважень, зокрема свободи слова і друку. При цьому громадяни мають впливати на суспільні рішення [5].

Соціологічні теорії, які стосуються соціального контролю в різних ситуаціях, зокрема схильності до правопорушень. У 60-х роках XX ст. з'явилась інноваційна версія теорії управління Тревіса Хірши, яка заснована на існуючих концепція громадського контролю [6]. Ця теорія застосовується в контексті девіантної поведінки і обгрунтовує підвищення правопорушень при відсутності контролю. Ця теорія є однією з низки соціологічних теорій. Теорія соціального контролю розглядає також норми поведінки в суспільстві, які потребують контролю або викликають агресію, зокрема йдеться про те, що суспільні групи, які дотримуються насильницьких норм, впливають на агресивний характер окремих членів суспільства. При цьому, не останнє місце в соціальному контролі поведінки відіграє релігійність. Стверджується, що релігійність зменшує міру насильства і правопорушень. Відповідно і різні політики мають розроблятись і створюватись на основі теорії соціального контролю [6].

Теорія нового публічного управління, яка змінює розуміння про- цесів публічного управління та адміністрування i виводить роботу уряду на новий результативний рівень. Nazmul Ahsan Kalimullah (2012 р.) стверджує, що новий публічний менеджмент (NPM) визначається на основі двох сфер: суспільний вибір і менеджерство [7]. Суспільний вибір у даному випадку розуміється в контексті турботи уряду про населення, а менеджерство стосується побудови зв’язків з організаціями у приватному секторі.

Теорії політичного контролю, сутність яких розширилась і стала застосовною у вимірі взаємодії кількох секторів. Так, Т. М. Мое (2005, 2015 р.) [8] у своєму дослідженні взаємовідносин бюрократії виокремлює дві площини: контроль внутрішньо організаційний (коли контролюються підлеглі і нижчі за рівнем влади органи) та контроль при виконанні політичних дій. Наголошується, що оскільки влада обирається, то чиновники можуть чинити політичні дії, особливо, якщо вони організовані профспілками державного сектору. Політична влада бюрократії розглядається в контексті переорієнтації сучасних теорій, що грунтується на аналізі поведінки виборців.

Теорії політики і бюрократії, як наголошується, значно применшують можливості бюрократів перетворити контрольні відносини у власні і мають свої інтереси, вбудовані в структуру, фінансування і діяльність уряду. У багатьох дослідженнях звертається увага не те, що бюрократи можуть відрізнятись від пересічних громадян політичними знаннями, інтересами, ефективністю, довірою, підтримкою державних ви- 
трат і бюджету для партій. Бюрократів часто сприймають і характеризують як загальний єдиний тип без розрізнення на конкретні професії 3 конкретними інтересами, які можуть значно відрізнятись один від одного. Здебільшого зосереджуються на національних виборах і мало приділяється уваги місцевим виборам, які можуть бути більш актуальними. Також всі зосереджені на явці виборців, а не на результатах виборів. Проте, є дослідження щодо ролі профспілок у виборчому процесі і можливостей їх впливу на своїх членів при голосування за окремих кандидатів [8].

Наступна група - це теорії та концепції, в основу яких покладено участь громадян та їх вплив на процеси демократичного прийняття рішення в публічному управлінні та адмініструванні. Так, теорія участі громадян розглядається як процес, який дає можливість приватним особам впливати на суспільні рішення i $є$ компонентом процесу демократичного прийняття рішень. Участь громадськості є засобом забезпечення того, що громадяни мають прямий голос у громадських рішеннях. Зазначається, що у зарубіжних дослідженнях терміни “громадянин”, “громадськість”, “участь”, “громадська участь” часто використовуються як взаємозамінні для позначення процесу, завдяки якому громадяни мають право голосу при прийнятті рішень у сфері державної політики [9].

E думка науковців (Ashley E. Nickels @ Jason D. Rivera, 2018), що концепції розвитку громадськості використовуються по-різному в різних академічних дисциплінах. Біль- ше того, важливим є те, яким чином певні визначення використовуються в академічних дослідженнях і в практиці на місцевій мові (в перекладі в інших державах) [10]. Йдеться про зміну парадигми розвитку громади із застосуванням концепції державного управління "Нова державна служба" (NPS) до розвитку громади, про участь державних управлінців та адміністраторів у плануванні і реалізації розвитку громади, що має привести до більш справедливого і стійкого, довгострокового розвитку [10].

Наголошується, що термін “громадська участь” і його сутність по відношенню до громадського прийняття рішень розвивається без загального консенсусу ні відносно його значення, ні відносно наслідків його використання. $Є$ також погляди щодо участі населення в плануванні певних дій або зусиль щодо розвитку громади, державно-управлінських рішень того, зокрема: участь громадян є занадто вартісною і тривалою, тому пропонується виключати громадян з даного процесу. У практиці багато програм участі громадян ініціюється у відповідь на реакцію громадськості на проект або дію, які пропонуються.

Виокремлено погляди на сутність і процеси політичної децентралізації. У контексті поглядів на роль політичної децентралізації задля розвитку громадського контролю представницьких органів влади цікавими є матеріали Світового Банку [11]. Мова йде про нову концепцію політичної децентралізації. Зазначається, що політична децентралізація спрямована на те, щоб дати громадянам або їх обранцям більше повноважень 
при прийнятті державних рішень. Наголошується, що такий процес часто асоціюють 3 плюралістичною політикою і представницьким урядом, але має враховуватись і те, що підтримувати демократію можна, надаючи громадянам або їх представникам більшого впливу при розробці і реалізації політики. Прибічники політичної децентралізації передбачають, що рішення, які приймаються за більш широкої участі, будуть більш інформативними та актуальними для різних інтересів суспільства, ніж рішення, які приймаються тільки національною політичною владою [11].

Концепція політичної децентралізації передбачає, що вибір представників з місцевих виборчих юрисдикцій дають можливість виборним посадовим особам краще знати потреби і бажання своїх виборців [11]. Саму децентралізацію розглядають як складний соціальний експеримент, який вимагає гнучкості та змін специфіки інструментів реалізації при одночасному закріпленні політичних і філософських принципів у Конституції і діючих структурах законів [11].

Децентралізацію і участь громадян розглядають $з$ позицій симбіотичних відносин, що призводить до певних протиріч. 3 одного боку, механізми участі громадян вважаються більш корисними при оцінюванні перспектив успішної децентралізації. Відповідно, дизайн децентралізації має враховувати можливості та обмеження, які накладаються існуючими каналами місцевої участі. 3 іншого боку, відсутність механізмів участі може розглядатись як мотивація для децентралізації і може до- помогти створити місцевий попит на канали з більш широкою участю для вираження місцевих переваг. Планування політики децентралізації має враховувати ці недоліки інформації i намагатися покращити глибину i ступінь участі громадян у діях місцевих органів влади. Реагування місцевих органів влади - це одне з головних обгрунтувань децентралізації, яке не може бути реалізованим, коли не має механізмів передачі інформації між місцевим органами влади та їх виборцями [11].

Привертають увагу кілька теорій i концепцій, які, на перший погляд, не мають нічого спільного з громадським контролем. Ці теорії з'явились як дослідження певних сфер (галузей) у публічному управлінні. Деякі 3 них були розроблені у 80-90-х роках XX ст. Тим не менш, вони зазнали певних модифікацій і використовуються задля формування форм i методів громадського контролю представницьких органів влади.

Mark C. Schug i Jennifer Fontanini ще у 1994 р. розглядали зміни у розумінні ролі економічних теорій у розвитку взаємовідносин між державою та економікою. Вони зробили акцент на історичному аналізі розвитку держави і впливу на неї теорії суспільного вибору та ролі уряду США в цьому процесі [12].

Інша теорія, яка взяла свій початок з криміналістики та соціальних наук, також на сучасному етапі широко використовується у сучасній вітчизняній науковій думці. Це стосується теорії соціального контролю. У сучасній зарубіжній науковій думці ця теорія розглядається також з різних позицій і використовується як 
основа для формування нових підходів до вирішення різних проблем і питань. Роль даної теорії найчастіше досліджують науковці Оксфордського університету.

Joan Higgins (2009) розглядає теорії соціального контролю соціальної політики. На її думку, концепція соціального контролю має вирішальне значення для пояснення, як зростає соціальна політика та які її наслідки. Це піднімає важливі питання про законність державного втручання, підтримки порядку і захисту свободи особистості [13]. Наголошується, що цей термін широко використовується в літературі по соціальній політиці, але мало існує досліджень його 3 різних значень і можливостей.

У сучасних наукових дослідженнях часто використовуються терміни “оптимальне управління”, “динамічне програмування”. Всі вони є характеристикою теорії оптимального управління. Теорія оптимального управління, на сучасному етапі, $є$ предметом дослідження в економіці, макро- та мікроекономіці та науці управління. Йдеться про розширення можливостей теорії оптимального управління та їх застосування. Розглядається застосування даної теорії для вироблення тіньової ціни [14].

Аналіз наукових поглядів на формування та розвиток контролю дав змогу узагальнити сфери громадського контролю представницьких органів влади та класифікувати їх за сферами публічного управління, а у відповідності зі змістом, сенсом та характеристиками теорій, концепцій, шкіл тощо за сферами впливу на життєдіяльність населення (рис.).

3 такого переліку наукових інтересів складно визначити критеpiї та можливості впливу громадян на сфери власної життєдіяльності. Відповідно й результативність громадського контролю також складно визначити. Фактично, публічна сфе-

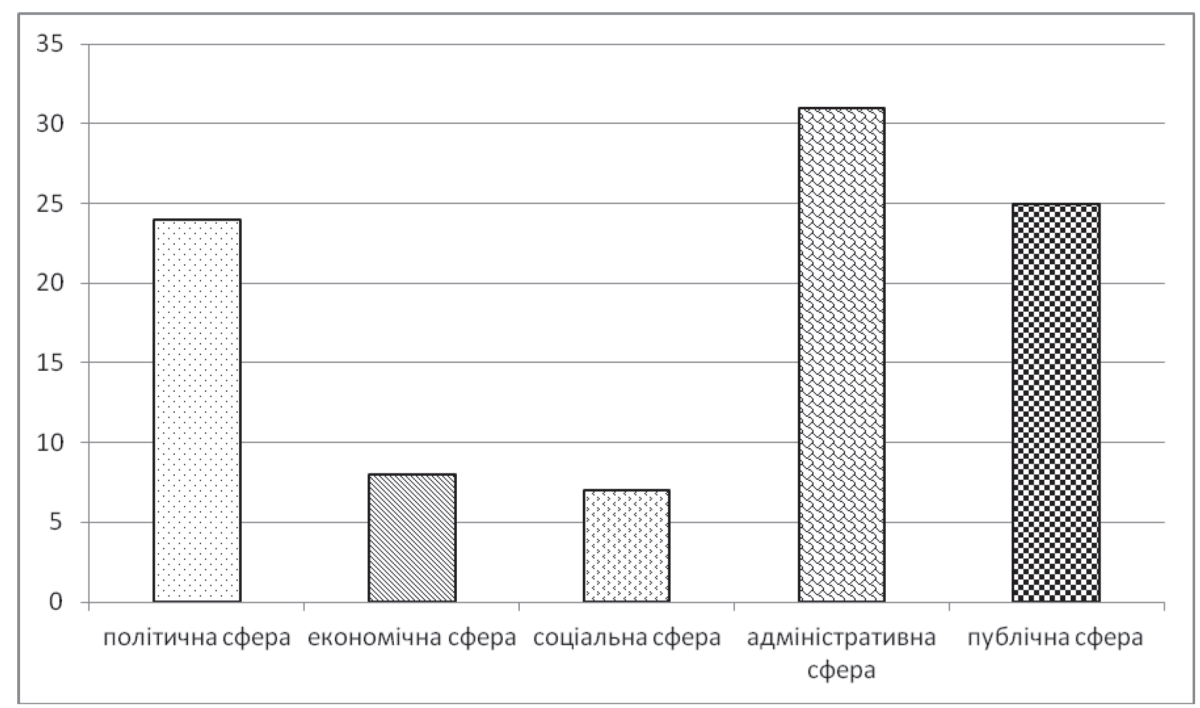

Діаграма кількісного аналізу зарубіжних наукових теорій, концепцій, шкіл щодо сфер громадського контролю представницьких органів влади (аналіз авторський, діаграма авторська) 
ра знаходиться осторонь впливу на проблеми розвитку держави і питань життєдіяльності. Основний вплив відбувається через представницькі органи та осіб, які в них працюють та які були обрані. Можна констатувати певний розрив між політичною, економічною, адміністративною сферами та соціальною і публічною. Так, найбільша кількість теорій, які вироблені задля проведення змін у публічному управлінні та адмініструванні, стосується адміністративної сфери. Дослідження ролі публічної сфери в процесі публічного управління на другому місці. Як показали проведені авторська систематизація та схематизація, йдеться про методологічні аспекти залучення громадян і вироблення методів їх участи в прийнятті рішень або плануванні громад.

Висновки. Проведений аналіз наукових джерел продемонстрував широкий спектр досліджень щодо громадського контролю представницьких органів влади, у тому числі в умовах децентралізації. Теоретико-методологічні засади формування та розвитку такого контролю систематизовано за напрямами досліджень, зокрема щодо: побудови демократичного суспільства, заснованого на політичній теорії; політичної децентралізації (політична сфера); побудови сталого демократичного суспільства; суспільних проблем демократичного суспільства; організації самого процесу управління; побудови взаємодії кількох секторів; залучення громадян до розвитку демократичного суспільства; збереження і контролю за персональними даними.
При цьому, найбільший вплив на вироблення методологій громадського контролю в організації соціально-економічної сфери життєдіяльності держави, безпеки та оборони чинять дослідження в таких наукових галузях, як: політологія, економіка, соціологія, управління (кібернетика). Саме тому, на наш погляд, результативність громадського контролю важко визначити. Можна тільки говорити про механізми та форми залучення громадян до прийняття рішень і до контролю.

Якщо ж підходити з позицій теоpiї нового публічного менеджменту, який є популярним серед досліджень в Україні, то не існує теорій або концептуальних підходів, які б системно розглядали відношення, поведінку i дії в контексті громадського контролю представницькими органами влади. Теоретичні наробки щодо “гарного менеджменту” не було включено, оскільки він не передбачає контролю з боку громадськості, а пропонує спільну діяльність задля розвитку держави через інші методи.

У багатьох джерелах будуються взаємозв'язки і взаємозалежності між цими термінами та виокремлюється більш “широке” розуміння та більш “вузьке”. Багато визначень повторюються зі зміною назви контролю. Здебільшого акцент робиться на контролі і нагляді за функціями органів влади. Це не дало можливості зробити кількісний аналіз взаємовпливів наукових теорій, концепцій, шкіл в контексті громадського контролю представницьких органів влади, оскільки у вітчизняній практиці не має на них посилань, а визначення громадського контролю 
стосуються здебільшого констатацій, що це чинник демократичного державотворення і залучення громадян.

\section{СПИСОК ВИКОРИСТАНИХ ДЖЕРЕЛ}

1. 10.1: Politics and Government. Retrieved from https://socialsci.libretexts.org/Bookshelves/ Sociology/Book\%3A_Sociology_ (Barkan)/10\%3A_Politics_and_the Economy/10.02\%3A_Politics_and_Government [in English].

2. Dr. Almon Leroy Way, Jr. The American system of government: politics \& government in the USA. Cyberland university of North America. Retrieved from https://www.proconservative. net/CUNAPolSci201PartTwoE2.sht$\mathrm{ml}$ [in English].

3. Jeanet Bentzen, Jacob Gerner Hariri, James A. Robinson. (2017). Power and Persistence: The Indigenous Roots of Representative Democracy. Retrieved from http://web.econ.ku.dk/bentzen/ Bentzen_roots.pdf [in English].

4. Randall G. (1997). A Theory of the Theory of Public Goods. Review of Austrian Economics, I, p. 1-22. Retrieved from https://cdn.mises.org/ rae10_1_1_2.pdf [in English].

5. William A. Galston. (2018). The Populist Challenge to Liberal Democracy. Journal of Democracy, II, p. 5-19. Retrieved from https://www.journalofdemocracy.org/articles/the-populistchallenge-to-liberal-democracy/ [in English].

6. Social Control and Self-Control Theories. (2008). Review of the Roots of Youth Violence, IV, Ch. 12. Ontario. Ministry of Children, Community and Social Services. Retrieved from http://www.children.gov.on.ca/htdocs/English/professionals/oyap/ roots/volume5/chapter12 social control.aspx [in English].
7. Nazmul Ahsan Kalimullah, Kabir M. Ashraf Alam, M. M Ashaduzzaman Nour. (2012). New Public Management: Emergence and Principles. Bup Journal, I, p. 1-22. Retrieved from https://www.pravo.unizg.hr/_download/repository/1-22.pdf [in English].

8. Moe T. M. (2005). Political Control and the Power of the Agent. Journal of Law. Economics, E Organization. Retrieved from https://sites.lsa.umich. edu/tsebelis/wp-content/uploads/ sites/223/2015/02/terry_moe.pdf [in English].

9. Planning Analysis: The Theory of Citizen Participation. Retrieved from https:// pages.uoregon.edu/rgp/PPPM613/ class10theory.htm [in English].

10. Ashley E. Nickels, Jason D. Rivera. (2020). Community Development and Public Administration Theory: Promoting Democratic Principles to Improve Communities. Wiley Online Library: Public administration. Retrieved from https://onlinelibrary.wiley.com/doi/epdf/10.1111/ puar.13167 [in English].

11. Political Decentralization. The World Bank Group. Decentralization $\mathcal{E}$ Subnational Regional Economics. Retrieved from http://www1.worldbank. org/publicsector/decentralization/ political.htm [in English].

12. Mark C. (1994). Schug and Jennifer Fontanini. Public Choice Theory and the Role of Government in the Past. Social Education, LVIII (I), p. 20-22. Retrieved from http://www.socialstudies.org/sites/default/files/publications/se/5801/580107.htm] [in English].

13. Joan Higgins. (2009, January 20). Social Control Theories of Social Policy. Journal of Social Policy, IX, p. 1-23. Published online by Cambridge University Press. Retrieved from https://www.cambridge.org/ core/journals/journal-of-social- 
policy/article/social-control-theoriesof-social-policy/3F8E3D6564EBB8 3A258B4B1FDCD4C64F [in English].

14. N. Van Long. (2001). Optimal Control Theory. International Encyclopedia of the Social \& Behavioral Sciences. Retrieved from https://www.sciencedirect.com/science/article/pii/ B0080430767005830.

\section{REFERENCES}

1. 10.1: Politics and Government. Retrieved from https://socialsci.libretexts.org/Bookshelves/ Sociology/Book\%3A_Sociology (Barkan)/10\%3A_Politics_and_the Economy $/ 10.02 \% 3 \mathrm{~A}$ Politics_and Government [in English].

2. Dr. Almon Leroy Way, Jr. The American system of government: politics \& government in the USA. Cyberland university of North America. Retrieved from https://www.proconservative. net/CUNAPolSci201PartTwoE2.sht$\mathrm{ml}$ [in English].

3. Jeanet Bentzen, Jacob Gerner Hariri, James A. Robinson. (2017). Power and Persistence: The Indigenous Roots of Representative Democracy. doi. org/10.1111/ecoj.12568. Retrieved from http://web.econ.ku.dk/bentzen/ Bentzen roots.pdf [in English].

4. Randall G. (1997). A Theory of the Theory of Public Goods. Review of Austrian Economics, I, p. 1-22. Retrieved from https://cdn.mises.org/ rae10_1_1_2.pdf [in English].

5. William A. Galston. (2018). The Populist Challenge to Liberal Democracy. Journal of Democracy, II, p. 5-19. Retrieved from https://www.journalofdemocracy.org/articles/the-populistchallenge-to-liberal-democracy/ [in English].

6. Social Control and Self-Control Theories. (2008). Review of the Roots of Youth Violence, IV, Ch. 12. Ontario.
Ministry of Children, Community and Social Services. Retrieved from http://www.children.gov.on.ca/htdocs/English/professionals/oyap/ roots/volume5/chapter12_social_ control.aspx [in English].

7. Nazmul Ahsan Kalimullah, Kabir M. Ashraf Alam, M. M Ashaduzzaman Nour. (2012). New Public Management: Emergence and Principles. Bup Journal, I, p. 1-22. Retrieved from https://www.pravo.unizg.hr/_download/repository/1-22.pdf [in English].

8. Moe T. M. (2005). Political Control and the Power of the Agent. Journal of Law. Economics, E्F Organization. Retrieved from https://sites.lsa.umich. edu/tsebelis/wp-content/uploads / sites/223/2015/02/terry_moe.pdf [in English].

9. Planning Analysis: The Theory of Citizen Participation. Retrieved from https:// pages.uoregon.edu/rgp/PPPM613/ class10theory.htm [in English].

10. Ashley E. Nickels, Jason D. Rivera. (2020). Community Development and Public Administration Theory: Promoting Democratic Principles to Improve Communities. Wiley Online Library: Public administration. doi. org/10.1111/puar.13167. Retrieved from https://onlinelibrary.wiley. com/doi/epdf/10.1111/puar.13167 [in English].

11. Political Decentralization. The World Bank Group. Decentralization $\mathcal{E}$ Subnational Regional Economics. Retrieved from http://www1.worldbank. org/publicsector/decentralization/ political.htm [in English].

12. Mark C. (1994). Schug and Jennifer Fontanini. Public Choice Theory and the Role of Government in the Past. Social Education, LVIII (I), p. 20-22. Retrieved from http://www.socialstudies.org/sites/default/files/publications/se/5801/580107.htm] [in English]. 
13. Joan Higgins. (2009, January 20). Social Control Theories of Social Policy. Journal of Social Policy, IX, p.1-23. Published online by Cambridge University Press. doi.org/10.1017/ S0047279400009521. Retrieved from https://www.cambridge.org/core/ journals/journal-of-social-policy/article/social-control-theories-of-social-
policy/3F8E3D6564EBB83A258B4B 1FDCD4C64F [in English].

14. N. Van Long. (2001). Optimal Control Theory. International Encyclopedia of the Social \& Behavioral Sciences. doi. org/10.1016/B0-08-043076-7/005830 . Retrieved from https://www.sciencedirect.com/science/article/pii/ B0080430767005830 